\title{
Decentralization, Democratization, And Social Protection In Indonesia: A Systematic Review of the Literature
}

\author{
Dharendra Wardhana ${ }^{1}$ \\ Ministry of National Development Planning/Bappenas - Indonesia
}

\begin{abstract}
This literature review seeks to provide a comprehensive and systematic review of evidence concerning decentralization and its impact on vulnerable groups through social protection (SP) programs with the specific case of Indonesia. Having explored six major databases with various keyword strings, the results lead to considerable gaps in the knowledge base for decentralization and social protection, particularly for cases in developing countries. Most of the literature is 'data free', based on theory, assumption, or conjecture. Four key issues have been generated out of extensive search results. First, the weak correlation and varied results of decentralization implementation and local service delivery. Second, the impact of decentralization on SP is unclear. Third, a country's current regulatory environment and administrative capacity, significantly determine the overall success of SP programs. Fourth is the potential features of decentralization that can be drawn upon to enhance SP.
\end{abstract}

Keywords: decentralization; democratization; social protection.

\footnotetext{
${ }^{1}$ Dharendra is a Planner Staff at Directorate of Planning for Demography and Social Protection, Ministry of National Development Planning/Bappenas RI, Email: dharendra.wardhana@bappenas.go.id 


\title{
Decentralization, Democratization, And Social Protection In Indonesia: A Systematic Review of the Literature
}

\author{
Dharendra Wardhana
}

\section{Introduction}

There is already a wide body of literature on the impact of decentralization and democratization on social protection (henceforth called SP) in developing countries. A number of important points can be observed out of the emerging consensus on the impact of decentralization and democratization on service delivery and the factors of importance in ensuring the implementation of social protection. Research from Shah and Thompson (2004) on the early phase of Indonesian decentralization conveys important findings that a lack of incentive or responsiveness of local governments to their residents inhibited the expected impact.

This study seeks to assess the major issues arising in the implementation of $\mathrm{SP}$ within the context of decentralization and democratization through a systematic review of the literature. The review is based on electronic bibliographic searches and it draws on various types of literature.

This paper is structured as follows: it provides a brief background to decentralization, democratization, and SP, before moving to outline the methodology used to search for, and review, the literature in this area. The following section presents a discussion of key issues emerging from this literature, focuses on Indonesia. The final section concludes with key messages.

\section{Theories of Democratization and Decentralization}

Democratization and decentralization have emerged as mechanisms for addressing a wide range of issues in public sector organizations around the world. They have also evolved as a consequence of much dissatisfaction with the results of centralized economic planning which then led reformers to decentralization to reduce the sizable control of the central government and induce broader participation in democratic governance (Smoke, 1994). One important assumption is that in being closer to the people, local authorities can more easily identify people's needs, and thus supply the appropriate form and level of public services (Oates, 1972).

Both democratization and decentralization can be regarded as highly controversial and contested activities that determine the locus of decision making power and disrupt established power relations. Likewise, Scott (2009) argues that decentralization is not a technical activity that takes place in a political vacuum. In a similar vein, Rees and Hossain (p. 582) further highlight that decentralization is more than a process associated with local government reform.

Meanwhile, a large theoretical literature on democratization has developed considerably. In the last sixty years, this body of work has been joined by a vast array of empirical studies in modern political science.

\subsection{Decentralization: Concepts and Dimensions}

One of the most critical prerequisites to translate decentralization from theory to practice is a clear understanding of the concept in a definition. A quick but 
thorough literature review from UNDP (1999) shows no single agreed definition of decentralization.

The fundamental premise commonly held by development stakeholders is that a decentralized public sector will be more effective and accountable to the people. However, the rapid implementation of decentralization reforms often leads to several problems. According to Joanis (2014), most of the problems result from the coexistence of multiple tiers of government in certain policy areas. Many countries have begun delegating their responsibility for social services to lower levels yet the results have been mixed (Faguet 2014, pp. 8-9). In the case of Indonesia, political expediency led to 'big-bang' decentralization but left the expenditure law unclear on assignments which subsequently had to be revised.

\subsection{Driving Factors of Implementation}

In their initial objectives, many decentralization experiments aim to reconstitute government, from a hierarchical, bureaucratic mechanism of top-down management to a system of nested self-governments characterized by participation and cooperation. As summarised by Firman (2010), decentralization is aimed at diminishing the dependence of the local government on central government; encouraging economic development; to improve accountability; and to institutionalize change.

Decentralization in Indonesia has opened up the possibility for grass-roots participation in the local political context and wider public participation. It has had diverse implications for the political changes desired by the people; at the very least it has allowed the discussion and debate on the idea of 'democracy' to flourish. The latest development, the restructuring of the election of leaders, is considered by many to be the culmination of this process of developing a 'grass-roots' democracy and good governance.

A confluence of economic and political factors characterizes Indonesia's experience of decentralization, as reported by Hofman and Kaiser (2006). They point out that economic and political upheaval following the crisis eventually triggered a 'big-bang' decentralization process. The fiscal, administrative and political autonomy of local government has thus increased significantly in a relatively short period of time. More importantly, the government in 2005 took a major decision to introduce direct elections for the positions of the regent, mayor, and governor whilst retaining the central government greater powers to influence policy at the local level through direct spending (Bennet, 2010, pp. 8-9).

Furthermore, regional proliferation-which is the by-product of decentralization-has caused a further disparity between regions. In many ways, Indonesia's story was a portrait of 'fixing the machine as it was running'.

\subsection{Modalities of Distributive Politics in a Decentralised and Democratic Regime}

Like markets, politics also distributes goods (see Booms \& Halldorson, 1973). Government programs channel cash, jobs, credit, and a myriad of other resources to citizens; elected officials mete out benefits to favored constituencies, and political parties distribute everything from leaflets to souvenirs in search of votes. Politics can also manage to influence taxes and transfers to redistribute income within society (Bird \& Zolt, 2005). 
Within the setting of decentralization, regional governments have plenty of room to create various entitlement programs. Enhanced by the values of more liberal democratization, the political distribution of goods becomes increasingly important, particularly in a location with a large vulnerable population (Bollen \& Jackman, 1985). Political authorities at different levels of government make choices about the distribution of goods to beneficiaries (Rondinelli, McCullough, \& Johnson, 1989). When the hold of these authorities on office depends on their winning elections, their choices become bound up with political strategies. Therefore, the modes of strategic distribution vary widely.

Many conceptual distinctions can be drawn among distributive strategies. Stokes et al (2013) propose to distinguish programs generating public goods from ones targeting individuals. Public goods might benefit all contributors, or they might create a subsidy for public expenditures of narrower geographic constituencies (pork-barrel politics as suggested by Aldrich, 1995). Political parties can make long-term and slow-moving investments in basic programs by campaigning, on the margins, offering 'tactical distributions' (Dixit \& Londregan, 1996). Incumbents have the advantage of controlling benefits exclusively or they might be controlled if their opponents are economic monopolists (Medina \& Stokes, 2007).

Figure 1 below depicts the categories of distributive politics with their different channels of distribution. As reiterated by Stokes et al (2013), there are two distinctions in distributive politics i.e. programmatic vis-à-vis non-programmatic distribution. The other important difference is between unconditional benefits and conditional exchanges.

For a distributive strategy to be programmatic, according to Stokes et al (2013), two things must be true. First, the criteria for distribution must be public. Second, the formal criteria of distribution must actually shape the distribution of resources.

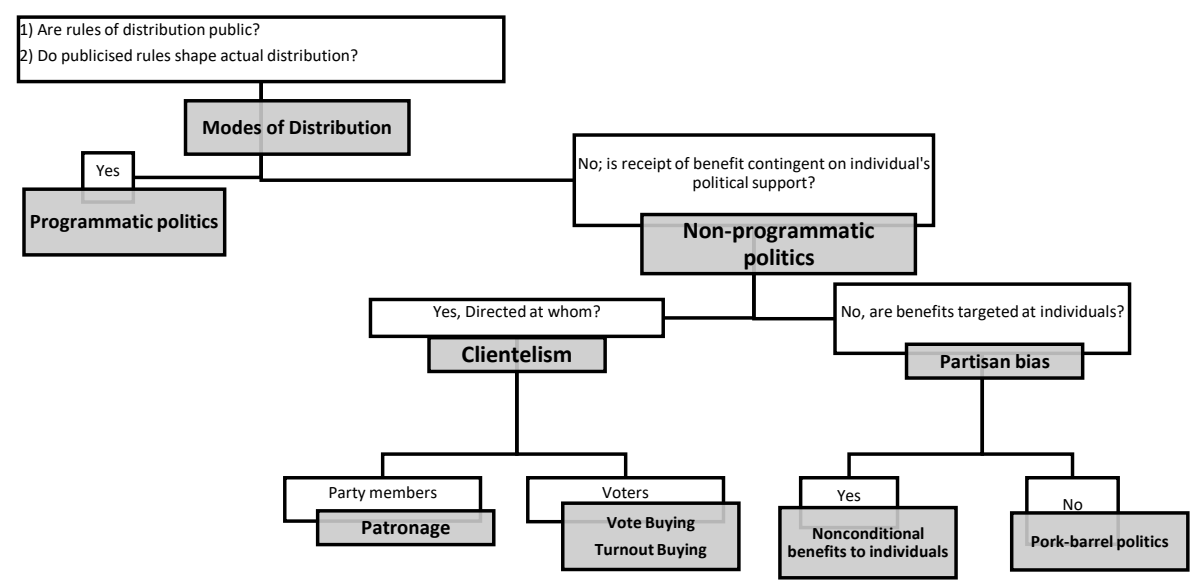

Figure 1. Types of Distributive Politics

Source: modified from Stokes et. Al., 2013

As a corollary of decentralization, Indonesia embarked upon democratization. The first democratic election was held in 1999. Subsequently, the new format of the 
presidential election was held in 2004 to choose the president and vice president in one ticket. Furthermore, the country has held direct local elections, known as pilkada, since June 2005 (Chen \& Priamarizki, 2014). The pilkada system allows citizens to directly vote for the more than 500 mayors and district heads and 34 governors. Direct Pilkada is considered as 'one of the most important achievements of Indonesia's democratic reform' (Fionna, 2015, p. 179). Prior to 2005, regional heads 'had been elected by provincial legislatures, giving elites ample opportunities to negotiate the outcome behind closed doors. The introduction of direct elections, by contrast, gave the final say in inter-elite competition in provinces to the electorate' (Mietzner, 2012, p. 213).

In spite of this, the Pilkada system had never been flawless. Various forms of patronage and clientelistic politics persisted and thrived. In many places, direct elections did not shake up the entrenched political traditions but resume the New Order' oligarchy (for a critical take on direct Pilkada from a pro-democratic point of view, see Choi, 2011). Despite these, experts concur that, in most instances, direct elections at local levels have led to greater participation from the ground.

\section{Concepts and Theories Underlying Social Protection}

Social protection (SP henceforth) is depicted as an important agenda and has been adopted by many national development strategies in recent years (Cook \& Kabeer, 2009, p. 3). A number of factors explain this heightened interest: the growing awareness that economic growth alone cannot deliver broadened development goals. Considering the recent trend and the popularity of SP, Barrientos, and Hulme (2010, p. 6) argue that a wide body of literature suggests that $\mathrm{SP}$ is an effective response to poverty and vulnerability in developing countries.

Undeniably, the definition of SP can be vague. There is an array of varying definitions which can lead to confusion. Increasing concern on the misused definition has been largely centered in a drift to a charity perspective, not a rights-based one (Standing, 2007, pp. 512-513).

In addition, Brunori and Reilly (2010) question whether almost any public intervention could be considered more or less directly part of the SP system (p. 7). Using this perspective, large government interventions such as education policy, pension systems, health care, and many other development policies will fall under a broad definition of SP. This, in fact, may impede the understanding of its specificity. Furthermore, Bender (2013) notes that different definitions of SP exist, which is not simply a problem of different streams of research across various academic disciplines (p. 4.1) but largely a reflection of different histories, cultural traditions, and prevailing values.

Evidence suggests that the focus of the term SP has been made to risk and vulnerability, which has an indirect contribution to poverty (Barrientos, Hulme, \& Shepherd, 2005, p. 8). In a similar vein, Devereux and Sabates-Wheeler (2004) argue against the popular perception of SP as social welfare programs for poor countries. Furthermore, their notion challenges the limited ambition of SP policy in practice, which has moved slightly from its origins in the 'social safety nets' discourse and aims to provide economic protection against livelihood shocks.

Recently, a number of authorities have acknowledged the social component of vulnerability and the importance to incorporate consistent support to chronically poor individuals (Brunori \& Reilly, 2010, p. 13). These considerations have found a 
synthesis in wider definitions endorsed by a number of international institutions and academics.

At this point, it is important to define SP and refer to the work of Devereux and Sabates-Wheeler (2004) that draws attention to distinctive conceptual and working definitions of SP. The former describes SP as public and private initiatives that provide assistance to the poor, protect the vulnerable against livelihood risks, and enhance the social status and rights of marginalized groups. They define SP as follows:

"Social Protection is the set of all initiatives, both formal and informal, that provide: social assistance to extremely poor individuals and households; social services to groups who need special care or would otherwise be denied access to basic services; social insurance to protect people against the risks and consequences of livelihood shocks; and social equity to protect people against social risks such as discrimination or abuse." (p.9)

Clearly, the above-mentioned SP definition is echoed strongly by many scholars and development institutions. For instance, Barrientos (2013) mentioned that SP is almost always associated with a range of public institutions, norms, and programs aimed at protecting people from contingencies. Broadly following the notions from ILO (2005), these can be grouped under three main headings: social insurance, social assistance, and labor market regulation.

\subsection{Dominant Paradigm}

In the past, SP programs are often perceived as the luxury of developed countries. Over the past 20 years, developing countries have embraced and adapted $\mathrm{SP}$ as an instrumental policy for achieving development goals. The speed of this expansion and the urgency of its ever-expanding aims has perhaps left limited room for reflection regarding the philosophical antecedents that underlie SP.

The wide variety of SP programs that have emerged globally provides evidence that the rich and dynamic ideological, political and social settings into which new programs and institutions are introduced are pivotal to setting a course for SP development trajectories, especially within the context of developing countries. However, as SP initiatives have expanded rapidly, practical issues related to legislation, targeting, financing, implementation, management, and technology often take the center stage.

There are several features distinguishing an emerging paradigm in developing countries. Naturally, they have a strong focus on poverty reduction and on providing support to the poorest (Barrientos \& Hulme, 2005), whereas in developed countries the emphasis of SP is on income maintenance and on protecting decent living standards for all, notably workers.

Discourse on SP especially in lower-middle-income countries is still unfolding. Attention from development institutions remains high with the reports on specific issues of SP from the World Bank (2018) and its close relation to the achievement of SDGs as written by ILO (2017). Similarly, discussion among scholars has been showing critical attention towards wider aspects of SP as compiled 
in IDS Bulletin on SP for social justice (2011), IDS Bulletin on 'graduation'? from SP (2015), and a special edition of Global Policy which discusses principles and practice of SP (2016). The most recent literature on SP points towards cross-cutting contemporary topics such as pre-empting climate risks in the long-term (Costella et al., 2017), how to build adaptive SP to mitigate climate-related ex treme events (Béné, Cornelius, \& Howland, 2018), how to provide trans-national SP for (undocumented) migrants and the role of sub-national governments (Dobbs \& Levitt, 2017), how to design SP using experimentation (Hanna \& Karlan, 2017). Coinciding with the process of democratization in many parts of the world is the dynamics of labour protest within the context of declining SP (Sil \& Wright, 2018) while the effect of globalization proxied by trade volume and its impact on SP for the poor in developing countries is elaborated clearly by Desai and Rudra (2018). The evolution of SP and varied implementation in developing countries are discussed extensively using the most updated information by Yi (2017).

The raison d'être of SP programs in developing countries can be traced back to the various crisis events and policy responses. For most parts of the history, the debate on social assistance has involved choices about whether the basic principle behind social provisioning will either be 'universalism', or selectivity through 'targeting' (Mkandawire, 2005). Under universalism, the entire population is definitely the beneficiary of social benefits as a basic right, while under targeting, eligibility to social benefits involves some kind of means-testing to determine the 'truly deserving' recipients. Policy regimes are hardly ever purely universal or completely based on targeting, they tend to lie somewhere between the two extremes on a continuum, and are often hybrid, but where they lie on this continuum can be decisive in spelling out individuals' life chances and in characterizing the social order. Inevitably, as mentioned by Devereux (2016), targeting as a mechanism for allocating scarce public resources efficiently and equitably has come under sustained attack, for two main reasons: 1) the apparent impossibility of achieving perfect targeting accuracy; and 2) ethical reasons - social divisiveness and perceptions that excluding some people from benefits is socially unjust.

\subsection{Challenges to the Dominant Paradigm}

There has been a very rapid extension of SP programs in developing countries over the last decade. This has focused on social assistance, as opposed to social insurance or labor market regulation (Barrientos \& Hulme, 2009) and has come in many forms: the introduction and extension of pure income transfers, such as non-contributory pensions or child based transfers; income transfers conditional on work, for example, public works or employment guarantee schemes; income transfers combined with services, such as conditional cash transfers or integrated social assistance schemes; and more recently, the development of integrated poverty reduction programs.

In Indonesia, the World Bank (2012) has attempted to undertake the Social Assistance Public Expenditure Review which provides a thorough analysis of SP budget effectiveness. Findings on this report show a significant increase in public expenditure for SP although it is argued that further improvement could be made. The performance of local government was discussed in brief with particular

\footnotetext{
${ }^{2}$ Graduation in this publication means leaving a SP programme after reaching a wellbeing threshold, once the participant has acquired a set of resources that is expected to equip them for a higher-income future livelihood.
} 
accentuation stress on the decreasing role of central government. The report also found that lack of legal clarity in technical guidance for sub-national government inhibits social assistance initiatives at the local level.

Nevertheless, the role of local government as a primary stakeholder in implementing SP has been considered important. It is emphasized particularly in rural communities characterized by high levels of poverty, inequality in the land, social status, literacy and/or political power (Bardhan \& Mookherjee, 2006). Also, research from Sumarto (2013) reiterates the positive impact of establishing regional institutions for poverty reduction. Yet, important findings from Crook and Sverrisson (2001) reveal the limited responsiveness of local government to the poor, determined mainly by the politics of local-central relations.

\subsection{The Significance of the Concepts and Theories Underlying SP}

Since the inception phase of SP, the debate on how to deliver the benefits dominated the discourse. It became clear when subsidy had proven ineffective to reach the poorest group. Energy subsidies as a core policy instrument for stabilizing prices and protecting the general welfare of the population seemed irrelevant when transport costs depend not only on fuel prices but also on road infrastructure and the quality and availability of public transport (Perdana, 2014). The most important point lead to the ineffectiveness is that fuel subsidies have unequal distributive effects. Since there is no restriction on the purchase of subsidized fuel in retail outlets, every household, regardless of their welfare status, has a similar chance to buy subsidized fuel (Widodo, Sahadewo, Setiastuti, \& Chaerriyah, 2012). This causes the subsidy to become regressive as Perdana (2014, p. 6) shows that high and uppermiddle classes consume more energy, and hence most of the subsidy allocation is enjoyed by these richer households.

Opting for a targeted approach, government programs in Indonesia have been the subject of extensive studies seeking to identify the factors that ensure or hinder success in delivering SP programs. Such factors that have received a lot of attention recently include the determination of the poverty line. Although its methodology adopts acceptable standards, the national poverty line in Indonesia (almost equivalent to the international absolute poverty standard of $\$ 1.5$ per day) is very distant from the income actually needed for a decent livelihood (Yusuf \& Rum, 2013). Therefore, the idea of increasing the standard to $\$ 2$ per day for the international poverty line, which is comparable across countries in PPP terms, is a critical aspiration (Sumner \& Edward, 2014).

In a decentralized and democratic regime, political scientists usually refer to the theoretical findings of partisan attachments and distributive politics. This is undeniably relevant to the case of burgeoning SP in Indonesia after 2005 when the direct election was officially launched. Yet, many political analysts believe there are also low-level operative factors playing in the Indonesian political system ( $\mathrm{S}$. Hidayat, 2009). What has become the dominant view among theorists or analysts is similar to the practitioner's rule of thumb: a party will not waste its resources on loyal supporters (or on die-hard haters), but instead spend on swing voters (Cox, 2009). The main reason is that parties will use largesse to change people's votes; swing voters, with no prior commitment to one party or another, will be uniquely responsive.

With the weakening of aliran politics in Indonesia, the pragmatic approach of social policy distribution is emulated in every political party (Ufen, 2008). The 
public often cannot distinguish between the differences in platforms between parties. Hadiz and Robison (2013) and Winters (2013) among other political scientists point out that the power of oligarchy has still not diminished, but rather has survived through different regimes in Indonesia. With deeply entrenched influence, political actors manage to utilize informal networks in their electoral area. Brokers undeniably play the most important role in garnering votes.

On the eve of elections, candidates often assemble successful team members (anggota tim sukses) or volunteers (relawan) to distribute cash or benefits to the neighborhoods (Aspinall \& Sukmajati, 2016, p. 5). Some benefits might be added if candidates manage to secure votes or win seats. Road improvement or infrastructures such as school building or housing are mainly built once candidates win the election. These days, candidates no longer rely on conventional benefits like cash, but they often promise to give more 'sustainable' programs.

Health care and free education are the most popular agenda candidates usually pledge in their campaigns (Rosser, 2012; Rosser \& Sulistiyanto, 2013). In this situation, there are attempts to move the focus away from regular elections to further strengthening of citizenship and democratizing the state by transforming citizens from passive actors independent relationships with politicians and political parties into active ones who can demand public goods provision from the state.

Unfortunately, however, most of the entitlement benefits were not designed properly and lacked inputs from wider stakeholders. For instance, health care is offered generously without preparing the supply side in a lagged region (B. Hidayat, Thabrany, Dong, \& Sauerborn, 2004). This ill-conceived strategy might backfire for the candidates as it will cause public dissatisfaction, eventually causing the vote to shift to other candidates or leading to reduced turnout. In a similar vein, some candidates who promised generous entitlement programs prior to elections decided to cancel mainly due to the fact that implementation would be unrealistic.

\section{Scoping Study and Search Results}

This section presents the process of identifying and collating findings and important results using potential keywords in relevant academic journal repositories or databases. The process is undertaken through several steps. First, a scoping study attempts to revisit the connection between relevant keywords. Second, the study delved into an electronic bibliographic database and website search. Third, a supplementary component was prioritizing papers that resulted from previous extensive searches. These search results are presented briefly in this section.

\subsection{Scoping Study and Field Mapping}

The purpose of a scoping study is to identify possible interconnection between fields relevant to the literature review. In this paper, a scoping study is used to refer to a systematic classification of various topics that might intersect with one another. The diagram below illustrates some of the main potential keywords on each topic. It is apparent from the diagram that topics on decentralization, democratization, and SP are interrelated to several sub-topics which might be plausible for further elaboration. However, field mapping in these clustered topics must be attempted to seek specific topics that lie at the intersection of decentralization, democratization, SP, and local governance. 


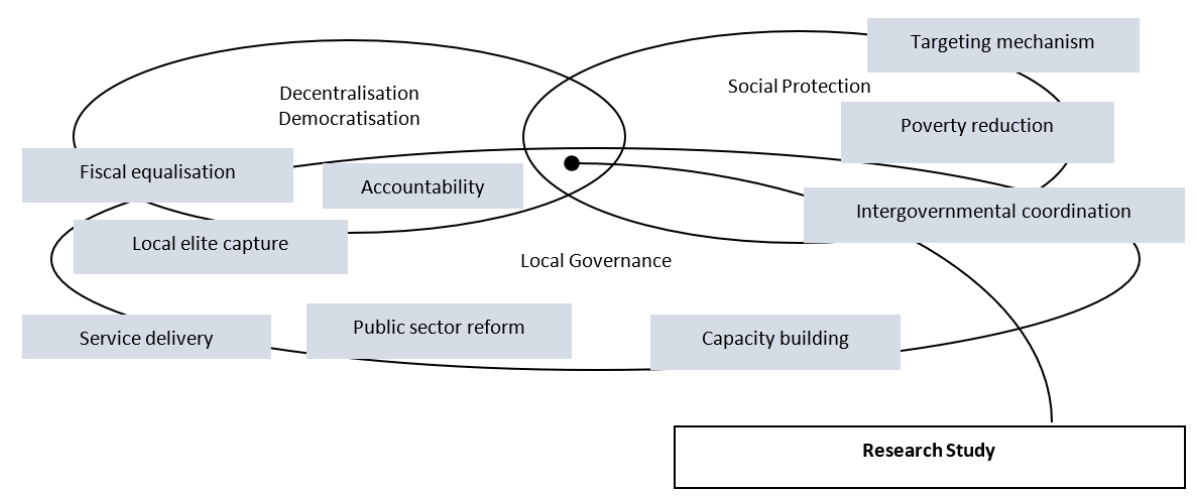

Figure 2. Field Map of Research Study

Equally important is to identify technical keywords for investigating important subtopics. In this paper, sets of keyword strings are used to give initial guidance on systematic search. Keyword strings for each topic domain are provided in Table 1 below.

Table 1. Keyword Search Strings

\begin{tabular}{|c|c|c|}
\hline Topic Domain & $\begin{array}{l}\text { String } \\
\text { No. }\end{array}$ & Search Strings \\
\hline Decentralization & 1 & $\begin{array}{l}\text { [decentrali*ation*] OR }[\text { devolution }] \text { OR } \\
\text { [deconcentration }] \text { AND ["fiscal equali*ation" }]\end{array}$ \\
\hline Democratization & 2 & $\begin{array}{l}\text { [democrati*ation] AND [election] AND ["local } \\
\text { politics"] AND ["local election”] AND [“direct } \\
\text { election"] }\end{array}$ \\
\hline Social Protection & 3 & $\begin{array}{l}\text { ["social protection”] OR ["social security"] OR } \\
\text { “"social assistance”] OR ["social insurance" }] \\
\text { AND ["poverty reduction"] AND ["gender"] }\end{array}$ \\
\hline Local Governance & 4 & $\begin{array}{l}\text { [accountability] AND ["good governance"] } \\
\text { AND ["public sector reform"] AND ["capacity } \\
\text { building"] AND ["service delivery"] AND } \\
\text { ["intergovernmental coordination"] }\end{array}$ \\
\hline
\end{tabular}

\subsection{Electronic Bibliographic Database and Website Search Results}

An extensive range of economic and social databases was searched (Google Scholar, EconLit, International Bibliography of Social Sciences (IBSS), SCOPUS, ASSIA, JOLIS), using several combinations of relevant search terms and Boolean logic operators over the period from January 1999 to January 2018. The detailed results are presented in Table 1. 
Table 2. Search Results on Peer-Reviewed Literature*

\begin{tabular}{|c|c|c|c|c|c|c|}
\hline Keywords & $\begin{array}{l}\text { Google } \\
\text { Scholar }\end{array}$ & EconLit & IBSS & SCOPUS & ASSIA & JOLIS \\
\hline $\begin{array}{l}\text { String No. } 1 \\
{[\text { Decentralization }]}\end{array}$ & 5,900 & 7,953 & 1,954 & 17,622 & 19,867 & 2,698 \\
\hline $\begin{array}{l}\text { String No. } 2 \\
\text { [Democratization] }\end{array}$ & 738 & 10,335 & 1,796 & 53,249 & 11,633 & 5,881 \\
\hline $\begin{array}{l}\text { String No. } 3 \text { [Social } \\
\text { Protection] }\end{array}$ & 18,000 & 26,838 & 2,354 & 23,031 & 27,670 & 5,716 \\
\hline $\begin{array}{l}\text { String No. } 4 \text { [Local } \\
\text { Governance] }\end{array}$ & 24 & 42,024 & 3,943 & 77,058 & 11,164 & 11,061 \\
\hline $\begin{array}{l}\text { String No. } 1 \\
\text { [Decentralization] AND } \\
\text { Indonesia }\end{array}$ & 862 & 1,781 & 298 & 533 & 146 & 91 \\
\hline $\begin{array}{l}\text { String No. } 2 \\
\text { [Democratization] AND } \\
\text { Indonesia }\end{array}$ & 261 & 1,568 & 246 & 556 & 47 & 50 \\
\hline $\begin{array}{l}\text { String No. } 3 \text { [Social } \\
\text { Protection }] \text { AND } \\
\text { Indonesia }\end{array}$ & 13,100 & 1,402 & 227 & 1,032 & 175 & 40 \\
\hline $\begin{array}{l}\text { String No. } 4 \text { [Local } \\
\text { Governance }] \text { AND } \\
\text { Indonesia }\end{array}$ & 2 & 2,782 & 333 & 544 & 188 & 28 \\
\hline $\begin{array}{l}\text { String No. } 1 \text { AND No. } 2 \\
\text { AND Indonesia }\end{array}$ & 2 & 408 & 42 & 184 & 19 & 6 \\
\hline $\begin{array}{l}\text { String No. } 1 \text { AND No. } 3 \\
\text { AND Indonesia }\end{array}$ & 35 & 297 & 62 & 54 & 20 & 1 \\
\hline $\begin{array}{l}\text { String No. } 1 \text { AND No. } 4 \\
\text { AND Indonesia }\end{array}$ & 5 & 586 & 35 & 118 & 47 & 5 \\
\hline $\begin{array}{l}\text { String No. } 2 \text { AND No. } 3 \\
\text { AND Indonesia }\end{array}$ & 3 & 175 & 44 & 23 & 17 & 1 \\
\hline $\begin{array}{l}\text { String No. } 2 \text { AND No. } 4 \\
\text { AND Indonesia }\end{array}$ & 2 & 663 & 71 & 51 & 22 & 3 \\
\hline $\begin{array}{l}\text { String No. } 3 \text { AND No. } 4 \\
\text { AND Indonesia }\end{array}$ & 17 & 324 & 64 & 16 & 27 & 6 \\
\hline $\begin{array}{l}\text { String No. } 1 \text { AND No. } 2 \\
\text { AND No. } 3 \text { AND } \\
\text { Indonesia }\end{array}$ & 4 & 85 & 6 & 3 & 6 & $\mathrm{O}$ \\
\hline $\begin{array}{l}\text { String No. } 1 \text { AND No. } 2 \\
\text { AND No. } 4 \text { AND } \\
\text { Indonesia }\end{array}$ & 1 & 262 & 14 & 20 & 13 & $\mathrm{O}$ \\
\hline $\begin{array}{l}\text { String No. } 1 \text { AND No. } 3 \\
\text { AND No. } 4 \text { AND } \\
\text { Indonesia }\end{array}$ & 48 & 149 & 3 & 2 & 10 & 1 \\
\hline
\end{tabular}




\begin{tabular}{lllllll}
\hline \multicolumn{1}{c}{ Keywords } & $\begin{array}{l}\text { Google } \\
\text { Scholar }\end{array}$ & EconLit & IBSS & SCOPUS & ASSIA & JOLIS \\
\hline $\begin{array}{l}\text { String No. 2 AND No. 3 } \\
\text { AND No. 4 AND }\end{array}$ & 3 & 94 & 3 & 2 & 5 & 0 \\
Indonesia & & & & & & \\
$\begin{array}{l}\text { String No. 1 AND No. } 2 \\
\text { AND No. 3 AND No. } 4 \\
\text { AND Indonesia }\end{array}$ & 4 & 69 & 1 & 1 & 4 & 0 \\
\hline
\end{tabular}

*) Search based on literature published 1999-2018

\subsection{Literature Search Results}

While the literature search resulted in an enormous number of studies, relatively few have been carried out that explicitly focus on the linkages between two topics or more. For instance, a search in EconLit came up with only 69 references (in English) to decentralization, democratization, and SP with the context of Indonesia for the period 1999 to 2018. SCOPUS, the major multidisciplinary database of bibliographic information, came up with only a single hit on a similar string and period. A search in the JOLIS identified 91 hits under the keywords 'decentralization in Indonesia', which became narrowed down to merely a handful of publications when the search was combined with other keywords combinations.

The result above, with relatively few scholarly publications having explicitly studied linkages between keywords surrounding the topics of decentralization, democratization, and SP is reflected in the widely used volume of the Handbook of Fiscal Federalism edited by Ahmad and Brosio (2008). None of the articles included in the book deals explicitly with SP (one article focuses on decentralization and service delivery). The comprehensive readings on Decentralization Briefing Notes edited by J. Litvack and Seddon (1998) contain only one relevant article.

This search on bibliographic databases yielded 120 possibly relevant 'hits' which were downloaded (abstracts where possible, titles otherwise) and reviewed. Of these only 14 were deemed relevant and the full paper obtained and reviewed. The websites together yielded 236 potentially important papers, which were obtained and reviewed. A review of the references contained within those papers yielded 56 additional papers for review. Thus, in total, 69 papers, articles, books, and reports were reviewed fully (marked by * in the reference list).

\subsection{Criteria for Prioritisation of Papers}

Papers in this area may have a broad or narrow focus, according to whether, for example, they focus on SP specifically or poverty more generally, whether they focus on the experience or viewpoint of a single country, a region, or more globally, and whether they focus on local governance specifically or decentralization more generally. Clearly, the relevance and importance of these papers to the specific issue of SP within decentralization will differ. Papers identified were therefore categorized according to three dimensions:

1. Sector: concerned with decentralization generally or local governance specifically;

2. Geography: specific to developing a country case or not;

3. Social Protection Specificity: cover all types or concerned with a type of SP specifically. 
These papers were then 'priority rated', according to these dimensions, as:

1. High priority: papers specifically concerned with decentralization, democratization, and SP and were developing country-specific. For instance, Priyadarshee and Hossain (2010); Fossati (2016).

2. Medium priority: papers concerned with decentralization more generally and were concerned with SP, but were not developing-country specific such as a paper by Ezcurra and Rodriguez-Pose (2009);

3. Low priority: papers concerned with decentralization more generally and were not SP-specific. For example, see P. Smoke and Lewis (1996); The World Bank (2003a); Turner, Podger, Sumardjono, and Tirthayasa (2004); and von Luebke (2009).

Only those papers rated as a medium or high priority were used as the basis for the discussion in this thesis (these are marked by \# in the reference list).

\subsection{Key Issues Arising from Literature Review}

There are considerable gaps in the knowledge base for decentralization, democratization, and SP, particularly for case studies in developing countries. Most of the literature is 'data free', based on theory, assumption, or conjecture. This is critical because there is no time limitation on decentralization and democratization, meaning that one cannot turn back to an arrangement of centralization in the long run. Below are the most important issues arising from the search results.

\subsubsection{Mixed Impacts on the Relationship between Decentralization, Democratization, and Improved Local Service Delivery}

One basis on which to assess the impact of decentralization is local service delivery in the country under question. This is important for two reasons in particular. First, basic services, such as health, education, water, and sanitation are systematically failing and especially failing poor people. Services are failing because they are falling short of their potential to improve outcomes. Second, these services are consumed and provided locally as most of them are categorized as non-tradable goods and services.

The Asia Foundation (from 2004) launched a series of studies to evaluate the impact of decentralization in Indonesia. Its findings suggest that early decentralization successfully promoted the establishment of three important conditions: (i) an increased awareness and respect for people's participation in the political process at the local level; (ii) a stronger commitment from local government to service delivery and significant pressure from communities to improve the quality of public services; and (iii) local governments working together and sharing information to solve problems together.

Nevertheless, case studies from three districts conducted by SMERU (2002) revealed the finding that many areas impose new levies which could potentially hamper the local business climate. A World Bank report (launched in 2008) discusses that while the poverty headcount dropped significantly after 1999-even considering the reversal in 2005- service delivery indicators show a mixed picture. Some indicators have improved, such as the primary school enrolment rate, but many others have only improved slightly since 1999 and some not at all. Likewise, recent evaluation of newly created regions shows that performance indicators are still far from what one might expect (see special report on decentralization by World Bank, 2011). 


\subsubsection{Unclear Impact of Decentralization on SP and Poverty Reduction}

Inter-related connections between decentralization and SP have rarely been explored. The majority of studies have focused on observable effects of decentralization on public sector outputs such as investment levels, public service provision, education and health indicators, macroeconomic stability, and other larger threads (Faguet 2014). While several studies have attempted to evaluate the performance of anti-poverty programs under decentralization, few have analyzed SP programs as the primary object of study.

None of the studies have looked at the impact of decentralization on potential beneficiaries or vulnerable groups (i.e. pregnant women, children, people with disabilities, elderly), with no analysis of local-financed SP program sustainability. Moreover, despite the potential of decentralized policymaking which enables higher female participation, understandings of social risks and gender inequality, in particular, have not been effectively integrated into SP policy and programming.

The link between decentralization and its impact on poverty reduction is ambiguous and largely influenced by country specificities. Bardhan (2002) highlights the mixed empirical experience of poverty reduction with decentralization in developing countries. The proximity of local government to the people has not universally led to better service provision in rural areas, undermined by the problems in coordination and lack of capacity. Additional to these problems are local elite capture which reduces the effectiveness and quality of services reaching the poor (Mansuri \& Rao, 2004).

An evaluation by the World Bank (2012) of Indonesian SP programs maintains that local governments have merely invested small budget shares for SP expenditure which caused under-coverage and sub-optimal progress. The report also mentions another problem which potentially impairs implementation: conflicting regulations between central and local government. For instance, currently, there are no harmonized local and national regulations regarding Jamkesmas (national health insurance scheme), Jamkesda (local health insurance scheme), and the National Social Security Law (which calls for universal coverage of all citizens with five insurance products including health).

Overall, the extent to which decentralization improves the quality of SP is unclear, but there may well be scope for mutual benefits when there are capable institutions, qualified personnel, and sufficient resources. It is relevant that capacity building is an important component of development (Fanany, Fanany, \& Kenny, 2009).

\subsubsection{The Regulatory Environment Determines the Impact of SP}

Newly formed authorities tend to promulgate their own regulations at the lower level. This is in line with the findings of Tanzi (1996) who stress the effects of decentralization that might cause excessive regulation. In addition to the general regulatory environment, important are those regulations that are directly pertinent to SP, as this sector tends to be amongst (if not the) most over-regulated. This can lead to a situation where regulations might be conflicting or overlapping, resulting in ineffective coordination and weak managerial control.

With regard to the Indonesian context, Law 32 the Year 2004 gives responsibility to local governments for the welfare provision. Therefore, local authorities are expected to have more comprehensive knowledge regarding their 
citizens. However, most resources are still under the control of the central government. For instance, although district governments were put in charge of managing (and operating) public health facilities when decentralization started in 2001, the central government is still involved in the deployment and financing of health personnel who work under civil service contracts (Olivia \& Yamauchi, 2012).

Meanwhile, several social insurance programs require specific conditions which can only be operated under a centralized arrangement. For instance, social insurance works only through the principle of the 'law of large numbers' by pooling funds from all participants to share risks as stipulated in Law 40 Year 2004 on Indonesian National Social Security System (Hadiz, 2004). The current regulatory environment will, in addition to that specifically related to SP, determine the effectiveness of programs in the decentralized setting. Important here is the harmony in terms of legal frameworks between a national regulatory system and regional laws, such as clear roles and responsibilities of regional stakeholders in nation-wide social insurance programs, particularly on issues such as benefit portability and standardization (Arifianto, 2006).

\subsubsection{The Potential of Decentralization and Democratization to Improve SP outcomes}

Most decentralization problems in Indonesia, as in many other developing countries, are related to governance issues. Decentralization in Indonesia has left much-unfinished business largely due to its hasty implementation (Sumarto, Vothknecht, \& Wijaya, 2014). Institutions are lacking key requirements for an effective management process i.e. absence of performance measures and an effective framework of constraints; unclear division of responsibilities between the different levels of government; insufficient human and institutional capacity of local governments; inappropriate incentives given by the structure of decentralized public finance.

It cannot be denied that decentralized Indonesia has made progress in addressing absolute poverty. There is confirmation of convergence in poverty rates at the district level (Sumarto et al. 2014, p.3). It clearly indicates that regions with initially higher poverty levels tend to experience a greater reduction in poverty.

Although SP programs have recently only had a few real champions among local leaders and bureaucrats, positive cases of local leadership signify the potential of responsive administration and local capacity to empower society and transform livelihoods (see evidence of Surabaya in Weiss, 2013).

Theoretically speaking, regional governments are supposed to have a better idea and knowledge of the needs of their people, ensuring that strategies meet local needs. In light of this premise, there are four determinants of local governments' ability to implement SP programs. Firstly, the capacity for income generation at the local level. Although the major source of local revenue comes from central government transfers, several local governments are able to generate their own income. The presence of natural resources in the region is a key factor affecting the amount localities can generate.

The second determinant is the performance in the delivery of public services. As fiscal capacity varies between regions, technical capacity also differs significantly. Several regions are still lagging behind due to the limitation of infrastructure. 
Third, are the governance aspects of decentralization. A strong accountability chain within a decentralized system is key to managing actors between institutions in the same region (horizontal coordination) and between central and local government (vertical coordination). Fourth is the regional institutional capacity for reducing poverty. Almost all districts are required to establish regional poverty reduction coordinating agencies (Tim Koordinasi Penanggulangan Kemiskinan Daerah, TKPKD), but around 20 percent of all districts have not yet established a TKPKD office as of 2010. This implies that many local leaders do not consider poverty reduction to be a foremost priority in their development plans. Sumarto (2013) provides an early claim that districts which established TKPKDs reduced poverty more significantly compared to regions without them.

\section{Conclusion}

In this paper, an attempt was made to provide a balanced review of the literature concerning SP in the context of decentralized and democratized governance, providing an overview of key issues that face developing countries.

A sizeable number of recent studies have focused on the exacerbation of inequality as a consequence of regional disparities. Interestingly, rarely has a significant attempt been made to clarify the impact of decentralization and democratization on SP. However, evidence on the likely impact of SP is virtually non-existent. Perhaps due to this, most of the literature is speculative about what might happen, rather than empirically-supported or verifiable, with views naturally quite polarised between those arguing for and against the benefits of decentralized and democratized government.

Although the limited time frame and the nature of the study imply that any conclusion should be treated with caution, our analysis indicates that four issues arise in terms of researchable areas: First, the weak correlation and varied results of decentralization implementation and local service delivery. This is because of a lack of systematic or comparative evidence and methodological problems which often lead to inconclusive results. Second, the impact of decentralization on SP and poverty reduction is quite unclear. Decentralized governments have to equip themselves with proper structure and adequate resources. Leadership factors are also instrumental in navigating the enhancement of local SP programs. Third, a country's current regulatory environment and administrative capacity will significantly determine the overall success of SP programs. The key here is establishing the likely balance of 'power' between national regulatory systems and local regulations. Although several programs embed 'monopolistic' characteristics, this does not exempt the significant role from regional-level players. Fourth, it is worth pointing out potential features of decentralization that can be drawn upon to enhance SP. Success stories and lessons learned from several regions indicate the potential of responsive local leaders in empowering society and transforming livelihoods through SP and participatory public policy (Lewis, 2014).

All in all, improved local governance can be associated with short-term action while in the long run governance needs to redesign intergovernmental transfer systems. Finally, given the data vacuum that exists with respect to the impact of decentralization on SP more specifically, there is clearly a substantial research agenda to be pursued before one can begin to better understand the relationship between decentralization, democratization, SP, and development outcomes. 


\section{References}

Ahmad, E., \& Brosio, G. (2008). Handbook of Fiscal Federalism. (E. Ahmad \& G. Brosio, Eds.). Cheltenham and Northampton: Edward Elgar Publishing Limited.*

Aldrich, J. H. (1995). Why Parties? The Origin and Transformation of Political Parties in America. Chicago and London: University of Chicago Press.

Arifianto, A. (2006). The New Indonesian Social Security Law: A Blessing or Curse for Indonesians? ASEAN Economic Bulletin, 23(1), 57-74.*

Asia Foundation. (2004). Indonesia Rapid Decentralization Appraisal (IRDA) 5th Report. Jakarta.

Aspinall, E., \& Sukmajati, M. (2016). Electoral Dynamics in Indonesia: Money Politics, Patronage and Clientelism at the Grassroots. Singapore: NUS Press Pte Ltd.

Bardhan, P. (2002). Decentralization of Governance and Development. Journal of Economic Perspectives, 16(4), 185-205.

Bardhan, P., \& Mookherjee, D. (2006). Decentralization and Accountability in Infrastructure Delivery in Developing Countries. The Economic Journal, 116(1997), 101-127. *\#

Barrientos, A. (2013). The Rise of Social Assistance in Brazil. Development and Change, 44(4), 887-910.*

Barrientos, A., \& Hulme, D. (2005). Chronic Poverty and Social Protection: Introduction. The European Journal of Development Research, 17(1), 1-7.

Barrientos, A., \& Hulme, D. (2009). Social Protection for the Poor and Poorest in Developing Countries: Reflections on a Quiet Revolution. Oxford Development Studies, 37(4), 439-456. *

Barrientos, A., Hulme, D., \& Shepherd, A. (2005). Can Social Protection Tackle Chronic Poverty? The European Journal of Development Research, 17(1), 823.*

Bender, K. (2013). The political economy of social protection reforms in developing countries: What is to be explained and how? In K. Bender, M. Kaltenborn, \& C. Pfleiderer (Eds.), Social Protection in Developing Countries: Reforming Systems (pp. 33-41). Abingdon, Oxon: Routledge.*

Béné, C., Cornelius, A., \& Howland, F. (2018). Bridging humanitarian responses and long-term development through transformative changes-some initial reflections from theWorld Bank's adaptive social protection program in the Sahel. Sustainability, 10(6), 1-17.

Bennet, R. (2010). Decentralizing Authority in Post-Suharto Indonesia: The Big Bang Theory, 1998-2010. New Jersey: Innovations for Successful Societies, Princeton University.

Bird, R., \& Zolt, E. (2005). Redistribution via taxation: The limited role of the personal income tax in developing countries. UCLA Law Review, 52(6), $1627-1696$.

Bollen, K., \& Jackman, R. (1985). Political Democracy and the Size Distribution of Income. American Sociological Review, 50(4), 438-457.

Booms, B., \& Halldorson, J. (1973). The Politics of Redistribution: A Reformulation. The American Political Science Review, 67(3), 924-933.

Brunori, P., \& Reilly, M. O. (2010). Social Protection for Development: A Review of Definitions. Firenze.*

Chen, B. J., \& Priamarizki, A. (2014). Abolishing Indonesia's Direct Local Elections: Missing the Forest for the Trees? Singapore: RSIS Commentary. 
Choi, N. (2011). Local Politics in Indonesia: Pathways to Power. (N. Choi, Ed.). Oxon and New York: Routledge.

Cook, S., \& Kabeer, N. (2009). Socio-economic security over the life course: A global review of social protection. Brighton.*

Costella, C., Jaime, C., Arrighi, J., Coughlan de Perez, E., Suarez, P., \& van Aalst, M. (2017). Scalable and Sustainable: How to Build Anticipatory Capacity into Social Protection Systems. IDS Bulletin, 48(4).

Cox, G. W. (2009). Swing Voters, Core Voters, and Distributive Politics. In I. Shapiro, S. C. Stokes, E. J. Wood, \& A. S. Kirshner (Eds.), Political Representation (pp. 342-357). New York: Cambridge University Press.

Crook, R., \& Sverrisson, A. S. (2001). Decentralization and poverty-alleviation in developing countries: a comparative analysis or, is West Bengal unique? (IDS Working Paper No. 130). Brighton: Institute of Development Studies at the University of Sussex. *\#

Desai, R. M., \& Rudra, N. (2018). Trade, poverty, and social protection in developing countries. European Journal of Political Economy.

Devereux, S. (2016). Is targeting ethical? Global Social Policy, 16(2), 166-181.

Devereux, S., McGregor, J. A., \& Sabates-Wheeler, R. (2011). Introduction: Social Protection for Social Justice. IDS Bulletin, 42(6), 1-9.

Devereux, S., \& Sabates-Wheeler, R. (2004). Transformative social protection (IDS Working Paper No. 232, IDS Workin). IDS Working Paper 232 (Vol. 232). Brighton: University of Sussex, Institute of Development Studies.*\#

Devereux, S., \& Sabates-Wheeler, R. (2015). Graduating from social protection? Editorial introduction. IDS Bulletin, 46(2), 1-12.*

Dixit, A., \& Londregan, J. (1996). The Determinants of Success of Special Interests in Redistributive Politics. The Journal of Politics, 58(4), 1132-1155.

Dobbs, E., \& Levitt, P. (2017). The missing link? The role of sub-national governance in transnational social protections. Oxford Development Studies, 45(1), 47-63.

Ezcurra, R., \& Rodriguez-Pose, A. (2009). Decentralization of Social Protection Expenditure and Economic Growth in the OECD. Publius: The Journal of Federalism, 41(1), 146-157.*\#

Fanany, I., Fanany, R., \& Kenny, S. (2009). The meaning of capacity building in Indonesia. Community Development Journal, 46(1), 89-103.

Fionna, U. (2015). ISEAS Perspective: Watching the Indonesian Elections 2014. (U. Fionna, Ed.). Singapore: Institute for Southeast Asian Studies.

Firman, T. (2010). Multi local-government under Indonesia's decentralization reform: The case of Kartamantul (The Greater Yogyakarta). Habitat International, 34(4), 400-405.

Fossati, D. (2016). Beyond "Good Governance": The Multi-level Politics of Health Insurance for the Poor in Indonesia. World Development, 87, 15-17.*\#

Hadiz, V. R. (2004). Decentralization and Democracy in Indonesia: A Critique of Neo-Institutional Perspectives. Development and Change, 35(4), 697-718.

Hadiz, V. R., \& Robison, R. (2013). The political economy of oligarchy and the reorganization of power in Indonesia. Indonesia, (96), 35-57.

Hanna, R., \& Karlan, D. (2017). Designing Social Protection Programs: Using Theory and Experimentation to Understand How to Help Combat Poverty. In A. V Banerjee \& E. Duflo (Eds.), Handbook of Economic Field Experiments (pp. 515-553). North Holland. 
Hidayat, B., Thabrany, H., Dong, H., \& Sauerborn, R. (2004). The effects of mandatory health insurance on equity in access to outpatient care in Indonesia. Health Policy and Planning, 19(5), 322-335.

Hidayat, S. (2009). Pilkada, Money Politics and the Dangers of "Informal Governance" Practices. In M. Erb \& P. Sulistiyanto (Eds.), Deepening Democracy in Indonesia?: Direct Elections for Local Leaders (Pilkada) (pp. 125-146). Singapore: Institute for Southeast Asian Studies.

Hofman, B., \& Kaiser, K. (2006). Decentralization, Democratic Transition, and Local Governance in Indonesia. In P. Bardhan \& D. Mookherjee (Eds.), Decentralization and Local Governance in Developing Countries (pp. 81124). Cambridge, MA: MIT Press.

International Labour Organization (ILO). (2005). Social Protection as a Productive Factor. Geneva.

International Labour Organization (ILO). (2017). World Social Protection Report 2017-19: Universal social protection to achieve the Sustainable Development Goals. Geneva.

Joanis, M. (2014). Shared accountability and partial decentralization in local public good provision. Journal of Development Economics, 107, 28-37.*\#

Lewis, B. D. (2014). Indonesian Intergovernmental Performance Grants: An Empirical Assessment of Impact. Bulletin of Indonesian Economic Studies, 50(3), 415-433. *\#

Litvack, J., \& Seddon, J. (1998). Decentralization Briefing Notes (WBI Working Papers). Washington DC.

Mansuri, G., \& Rao, V. (2004). Community-Based and -Driven Development: A Critical Review. The World Bank Research Observer, 19(1), 1-39.

Medina, L. F., \& Stokes, S. C. (2007). Monopoly and monitoring: an approach to political clientelism. In He. Kitschelt \& S. I. Wilkinson (Eds.), Patrons, Clients and Policies: Patterns of Democratic Accountability and Political Competition (pp. 68-83). Cambridge and New York: Cambridge University Press.

Mietzner, M. (2012). Indonesia's democratic stagnation: Anti-reformist elites and resilient civil society. Democratization, 19(2), 209-229.

Mkandawire, T. (2005). Targeting and Universalism in Poverty Reduction (Social Policy and Development Programme No. 23). Social Policy and Development Programme. Geneva.

Oates, W. E. (1972). Fiscal Federalism. New York: Harcourt Brace Jovanovich Inc.

Olivia, S., \& Yamauchi, C. (2012). Survey of recent developments. Bulletin of Indonesian Economic Studies, 48(2), 143-171.*

Perdana, A. A. (2014). The Future of Social Welfare From Fossil-Fuel Subsidies to Better Social Protection. Geneva: The International Institute for Sustainable Development.

Rondinelli, D., McCullough, J., \& Johnson, R. (1989). Analyzing Decentralization Policies in Developing Countries: a Political-Economy Framework. Development and Change, 20(1), 57-87.*

Rosser, A. (2012). Realizing Free Health Care for the Poor in Indonesia: The Politics of Illegal Fees. Journal of Contemporary Asia, 42(2), 255-275.

Rosser, A., \& Sulistiyanto, P. (2013). The politics of universal free basic education in decentralized Indonesia: Insights from Yogyakarta. Pacific Affairs, 86(3), $539-560$.

Scott, Z. (2009). Decentralization, local development, and social cohesion: an analytical review (GSDRC Research Papers No. May 2009). Birmingham: 
University of Birmingham. Governance and social development resource center (GSDRC).*\#

Sil, R., \& Wright, T. (2018). The dynamics of labor protest in an era of declining social protection. Economy and Society.

SMERU. (2002). Regional Autonomy and the Business Climate: Three Kabupaten Case from West Java. Jakarta.

Smoke, P. (1994). Local government finance in developing countries. The case of Kenya. Nairobi: Oxford University Press.*

Smoke, P., \& Lewis, B. D. (1996). Fiscal Decentralization in Indonesia: A New Approach to an Old Idea. World Development, 24(8), 1281-1299.*

Standing, G. (2007). Social protection. Development in Practice, 17(4-5), 511-522.* Statistics Indonesia. (2014, January). Berita Resmi Statistik No. 06/01/Th. XVII Profil Kemiskinan di Indonesia September 2013. Jakarta: Statistics Indonesia.

Stokes, S. C., Dunning, T., Nazareno, M., \& Brusco, V. (2013). Brokers, Voters, and Clientelism: The Puzzle of Distributive Politics. New York, N.Y.: Cambridge University Press.

Sumarto, S. (2013, December). Does Decentralization Lessen or Worsen Poverty? Evidence from Post-'Big Bang' Indonesia. California: Stanford University.*\#

Sumarto, S., Vothknecht, M., \& Wijaya, L. (2014). Explaining regional heterogeneity of poverty: evidence from a decentralized Indonesia. In H. Hill (Ed.), Regional Dynamics in a Decentralized Indonesia (pp. 285-314). Singapore: ISEAS Publishing.**

Sumner, A., \& Edward, P. (2014). Assessing Poverty Trends in Indonesia by International Poverty Lines. Bulletin of Indonesian Economic Studies, 50(2), $37-41 .^{*}$

Tanzi, V. (1996). Fiscal Federalism and Decentralization: A Review of Some Efficiency and Macroeconomic Aspects. In Annual World Bank Conference on Development Economics 1995 (pp. 295-316). Washington DC: The World Bank.*

Turner, M., Podger, O., Sumardjono, M. S., \& Tirthayasa, W. K. (2004). Decentralization in Indonesia: Redesigning the State. Manila: Asia Pacific Press.*

Ufen, A. (2008). From aliran parties to dealignment: political in post-Suharto Indonesia. South East Asia Research, 16(1), 5-41.

Ulriksen, M. S., \& Plagerson, S. (2016). The principles and practice of social protection. Global Social Policy, 16(2), 127-131.

UNDP. (1999). Decentralization: a Sampling of Definitions (Joint UNDPGovernment of Germany Evaluation Working Paper of the UNDP Role in Decentralization and Local Governance). New York.*

von Luebke, C. (2009). The political economy of local governance: findings from an Indonesian field study. Bulletin of Indonesian Economic Studies, 45(2), 201230.*

Weiss, S. (2013). Surabaya's Mrs. Mayor: Indonesia's Best-Kept Secret. Retrieved from

Widodo, T., Sahadewo, G. A., Setiastuti, S. U., \& Chaerriyah, M. (2012). Impact of Fuel Subsidy Removal on Government Spending. In X. Shi \& F. Kimura (Eds.), Energy Market Integration in East Asia: Theories, Electricity Sector and Subsidies (pp. 173-206). Jakarta: ERIA Research Project Report 201117.

Winters, J. A. (2013). Oligarchy and Democracy in Indonesia. Indonesia, (96), 1133. 
World Bank. (2003a). Decentralizing Indonesia: A Regional Public Expenditure Review Overview Report. Washington, DC.*

World Bank. (2003b). World Development Report 2004: Making Services Work for Poor People. Washington, DC.

World Bank. (2008). Spending for Development: Making the Most of Indonesia's New Opportunities. Washington, DC.

World Bank. (2011). Laporan Hasil Evaluasi Daerah Otonom Hasil Pemekaran. Jakarta, Indonesia.

World Bank. (2012). Public Expenditure Review Summary - Social Assistance Program and Public Expenditure Review 1. Washington, DC.

World Bank. (2018). The State of Social Safety Nets 2018. Washington, DC: World Bank.

Yi, I. (2017). Towards Universal Health Care in Emerging Economies: Opportunities and Challenges. (I. Yi, Ed.). London: Palgrave Macmillan.

Yusuf, A. A., \& Rum, I. A. (2013). Living beyond \$ 2 a day: How Indonesia has progressed (Working Paper in Economics and Development Studies No. 201313). Bandung. 